\title{
Serum Helicobacter pylori Flid antibody and the risk of gastric cancer
}

\author{
Hailin Li ${ }^{1}$, Bing Zhang ${ }^{1}$, Xiaomeng Hu${ }^{1}$, Yingzi Dong ${ }^{1}$, Qing Fan ${ }^{2}$, Fang Guo ${ }^{1}$, Xiyun \\ Ren ${ }^{1}$, Haibo Zhou ${ }^{1}$, Wenjing Tian ${ }^{1}$, Yashuang Zhao ${ }^{1}$ \\ ${ }^{1}$ Department of Epidemiology, College of Public Health, Harbin Medical University, Harbin, Heilongjiang Province, P. R. China \\ ${ }^{2}$ Xiangfang Center for Disease Control and Prevention, Harbin, Heilongjiang Province, P. R. China \\ Correspondence to: Wenjing Tian, email: twj8267@sina.com \\ Yashuang, Zhao, email: zhao_yashuang@263.net \\ Keywords: H. pylori FliD protein, H. pylori CagA protein, serum antibody, gastric cancer, case-control study \\ Received: November 07, $2015 \quad$ Accepted: February 23, $2016 \quad$ Published: March 8, 2016
}

\section{ABSTRACT}

FliD and CagA are important virulence factors of $\boldsymbol{H}$. pylori. We aimed to evaluate the screening values of FliD and CagA for gastric cancer (GC). Serum samples were obtained from 232 cases and 266 controls in a case-control study. Unconditional multivariate logistic regression with odds ratios (ORs) and $95 \%$ confidence intervals (CIs) was used to analyze the relationships between FliD, CagA and GC. The sensitivities, specificities and receiver operating characteristic (ROC) curves were calculated. Finally, the combined screening values of FliD, FlaA, NapA and CagA were assessed based on discriminant analysis. In all subjects, the associations of FliD and CagA with GC were evident with ORs (95\% CIs) of 7.6 (4.7-12.3) and 2.5 (1.6-3.8), respectively $(* p<0.001)$. The areas under ROC curves (AUCs) for FliD and CagA were 0.800 and 0.653 , respectively. The AUC for the combination of FliD, FlaA and NapA was 0.915 , which represented an increase of 0.115 over that of FliD alone $(* p<0.001)$. These findings indicate that the FliD antibody is associated with GC and could exhibit high validity as a biomarker in screening for GC patients. The combination of FliD, FlaA and NapA improved the screening validity.

\section{INTRODUCTION}

According to GlOBACAN 2012, gastric cancer (GC) is the fifth most common cancer in terms of incidence and the third-leading cause of cancer death worldwide. Moreover, half of the world's GC occurs in Eastern Asia, primarily China [1]. Currently, the reliable methods for identifying subjects who are at a high risk of GC are still limited to gastroscopy and biopsy, but these methods are invasive, expensive and time-consuming [2,3]. Therefore, noninvasive and acceptable biomarkers for $\mathrm{GC}$ are urgently needed.

Helicobacter pylori (H. pylori) has been classified as a type- 1 carcinogen by the World Health Organization (WHO) and the International Agency for Research on Cancer (IARC) [4]. A meta-analysis of 42 studies demonstrated that $H$. pylori infection is associated with a 2-fold increase in the risk of developing gastric adenocarcinoma [5]. Additionally, another meta-analysis revealed a reduction in the risk of GC following $H$. pylori eradication with a pooled RR of 0.65 [6]. Thus, population- wide screening for and eradication of $H$. pylori infection may be a valid strategy for GC prevention. However, although more than half of the world's population is infected with $H$. pylori [7], the majority of individuals infected with this bacterium are completely asymptomatic and do not demonstrate any severe pathology throughout their lives. Only $1-3 \%$ of infected individuals will eventually develop GC $[8,9]$. Therefore, it has been postulated that these different outcomes of infection may be partly due to differences in the virulence factors of the infecting $H$. pylori strains [10].

$H$. pylori has a wide variety of immunogenic virulence factors, and the host responses directed against these factors accordingly generate different immune patterns that may be associated with the pathogen-related $\mathrm{GC}$ risk to some extent [11]. One study reported that seropositivities for four proteins (i.e., Omp, HP0305, HyuA, and $\mathrm{HpaA}$ ) are associated with 1.5- to three-fold increases in the risk of $\mathrm{GC}$ among Chinese populations [12]. GroES is a dominant GC-related antigen with a much higher seropositivity in GC cases (64.2\%) compared with 
gastritis (30.9\%) and duodenal ulcer cases (35.5\%) [13]. However, these studies only examined the associations of H. pylori virulence factors with GC risk and did not assess the validities of these factors as GC screening markers.

The flagellar hook-associated protein (FliD) is an important $H$. pylori virulence factor that enables flagellin monomers to assemble into a flagella and is thus essential to bacterial motility as demonstrated by infections of mice with a fliD-mutant $H$. pylori [14]. Flagella-providing motility further contributes to $H$. pylori colonization and infection [15-17]. Additionally, the FliD protein induces specific antibodies in nearly all infected individuals [18]. Therefore, we performed the present study to assess the association between seropositivity for the antibody against $H$. pylori FliD and the risk of GC and to explore the application of the serum FliD antibody as a novel biomarker for GC. Furthermore, we also studied and assessed the screening value of the antibody against the typical virulence factor cytotoxin-associated gene A (CagA). We further explored the combined screening validity of FliD, CagA, flagellin A (FlaA), and neutrophilactivating protein (NapA), which are proteins that we have previously studied $[19,20]$.

\section{RESULTS}

\section{Subject characteristics}

The basic demographic and clinical characteristics, behavior, family history of GC and serologic test results for $H$. pylori are presented in Table 1. The differences in the BMI, years of education, smoking, alcohol consumption, H. pylori infection and family history of GC distributions between the cases and controls were statistically significance $\left({ }^{*} p<0.05\right)$. Of the 232 patients with GC, only 9 had gastric cardia cancer; 14 (7.2\%) of the cases were in stage I, $16(8.2 \%)$ were in stage II, 143 $(73.7 \%)$ were in stage III, and $21(10.8 \%)$ were in stage IV. The rates of seropositivity for $H$. pylori in the case and control groups were $59.7 \%$ and $48.0 \%$, respectively.

\section{Cloning and expression of the recombinant protein}

The nucleotide homology of the 2058-bp cloned fliD gene relative to $H$. pylori strain J99 was $94.41 \%$ (Supplementary Figure S1) [21]. The amplified cagA fragment was exactly $2247 \mathrm{bp}$, and the homology with $H$. pylori strain 26695 was $99.96 \%$ (Supplementary Figure S2) [22]. After adding IPTG, bands of rFliD and rCagA with predicted molecular weights of $92 \mathrm{kDa}$ and $103 \mathrm{kDa}$ were found, respectively, in the ultrasonic supernatants and precipitates of the cell lysates by sodium dodecyl sulfate polyacrylamide gel electrophoresis (SDS-PAGE). Finally, the purified soluble recombinant proteins were obtained (Figure 1).

\section{Association between seropositivity for FliD and CagA antibody and GC}

As illustrated in Table 2, the associations between H. pylori FliD serum antibody and GC were statistically significant with adjusted odds ratios (ORs) (95\%CIs) of $10.6(5.2-21.6), 6.5(3.0-14.0)$, and $7.6(4.7-12.3)$ in the H. pylori-positive and -negative subjects and the overall subjects (i.e., irrespective of $H$. pylori status), respectively $(* p<0.001)$. Strong, significant dose-response relationships between the serum FliD antibody levels and GC were observed in these three populations ( $* p<0.001$; Table 3 ).

As presented in Table 2, seropositivity for the CagA antibody was also significantly linked to the risk of $\mathrm{GC}$ with $\mathrm{OR}_{\text {adjusted }}(95 \% \mathrm{CI})$ values of 3.0 (1.6-5.9), 3.8 (1.9-7.7), and 2.5 (1.6-3.8) in the H. pylori-positive and -negative subjects and the overall subjects, respectively $\left(*_{p}<0.01\right)$. Significant dose-response relationships between the serum CagA antibody levels and GC were also observed $(* p<0.001$; Table 3$)$.

\section{Screening utilities of the serum FliD and CagA antibodies for GC}

According an receiver operating characteristic (ROC) analysis of FliD in the H. pylori-positive subjects, the optimal FliD cutoff value for GC was 0.1007 , which provided a sensitivity of $67.4 \%$ and a specificity of $82.5 \%$. The optimal cutoff value was 0.1263 for the $H$. pylorinegative subjects, which resulted in a sensitivity of $83.1 \%$ and a specificity of $55.4 \%$. The optimal FliD cutoff value was 0.1153 in the overall group of subjects, and this cutoff generated a sensitivity of $78.9 \%$ and a specificity of $64.3 \%$. When the optimal CagA cutoff values were set at $0.0463,0.0367$ and 0.0463 for the $H$. pylori-positive, $H$. pylori-negative and overall subjects, the sensitivities were $81.8 \%, 73.0 \%$ and $83.2 \%$, and the specificities were $42.5 \%, 56.9 \%$ and $39.1 \%$, respectively (Table 4 ). The areas under ROC curves (AUCs) for FliD and CagA were 0.800 and 0.653 , respectively, in the overall groups of subjects (Figure 2).

\section{Screening utility of the combination of the serum FliD, CagA, FlaA and NapA antibodies for GC}

In the present paper, the combined screening validities of FliD, FlaA, NapA and CagA generated by discriminant analysis were also analyzed. As illustrated in Table 5, the AUC and sensitivity of the combination of FliD and FlaA was significantly greater than that of FliD alone. Regarding the combination of FliD, FlaA and NapA, although the AUC was not significantly increased compared to that of the combination of FliD and FlaA, the sensitivity (at the specificity of $90 \%$ ) was significantly increased by $10.6 \%$ in the $H$. pylori-positive subjects. Similarly, in $H$. pylori-negative and overall subjects, the 
Table 1: Characteristics of the study subjects

\begin{tabular}{|c|c|c|c|c|c|}
\hline \multirow{2}{*}{ Variables } & \multicolumn{2}{|c|}{ Case $(\mathrm{N}=232)$} & \multicolumn{2}{|c|}{ Control (N=266) } & \multirow{2}{*}{$\boldsymbol{P}^{*}$} \\
\hline & $\mathbf{N}$ & $\%$ & $\mathbf{N}$ & $\%$ & \\
\hline Age (years, mean \pm SD) & \multicolumn{2}{|c|}{$59.6 \pm 10.6$} & \multicolumn{2}{|c|}{$57.7 \pm 10.6$} & 0.055 \\
\hline \multicolumn{6}{|l|}{ Sex } \\
\hline Male & 174 & 75.0 & 179 & 67.3 & 0.059 \\
\hline Female & 58 & 25.0 & 87 & 32.7 & \\
\hline \multicolumn{6}{|l|}{ BMI } \\
\hline$<18.5$ & 24 & 11.8 & 2 & 0.8 & $<0.001$ \\
\hline $18.5-24.9$ & 135 & 66.5 & 174 & 67.2 & \\
\hline $25.0-29.9$ & 36 & 17.7 & 76 & 29.3 & \\
\hline$\geq 30.0$ & 8 & 3.9 & 7 & 2.7 & \\
\hline \multicolumn{6}{|l|}{ Years of education } \\
\hline$\leq 8$ & 131 & 63.9 & 151 & 57.9 & 0.019 \\
\hline $9-11$ & 46 & 22.4 & 87 & 33.3 & \\
\hline$\geq 12$ & 28 & 13.7 & 23 & 8.8 & \\
\hline \multicolumn{6}{|l|}{ Smoking status } \\
\hline Ever & 133 & 65.5 & 119 & 45.6 & $<0.001$ \\
\hline Never & 70 & 34.5 & 142 & 54.4 & \\
\hline \multicolumn{6}{|l|}{ Alcohol drinking status } \\
\hline Ever & 121 & 59.3 & 99 & 38.1 & $<0.001$ \\
\hline Never & 83 & 40.7 & 161 & 61.9 & \\
\hline \multicolumn{6}{|l|}{ H. pylori serostatus } \\
\hline Positive & 132 & 59.7 & 120 & 48.0 & 0.011 \\
\hline Negative & 89 & 40.3 & 130 & 52.0 & \\
\hline \multicolumn{6}{|l|}{$\begin{array}{l}\text { Family history of gastric } \\
\text { cancer }\end{array}$} \\
\hline Positive & 20 & 10.1 & 2 & 0.8 & $<0.001$ \\
\hline Negative & 179 & 89.9 & 259 & 99.2 & \\
\hline \multicolumn{6}{|l|}{ Locations } \\
\hline Non cardia & 223 & 96.1 & & & \\
\hline Cardia & 9 & 3.9 & & & \\
\hline \multicolumn{6}{|l|}{ Depth of invasion } \\
\hline $\mathrm{T} 1$ & 17 & 9.2 & & & \\
\hline $\mathrm{T} 2$ & 12 & 6.5 & & & \\
\hline $\mathrm{T} 3$ & 15 & 8.2 & & & \\
\hline $\mathrm{T} 4$ & 140 & 76.1 & & & \\
\hline
\end{tabular}

(Continued) 


\begin{tabular}{|c|c|c|c|c|c|}
\hline \multirow{2}{*}{ Variables } & \multicolumn{2}{|c|}{ Case $(\mathrm{N}=232)$} & \multicolumn{2}{|c|}{ Control (N=266) } & \multirow{2}{*}{$P^{*}$} \\
\hline & $\mathbf{N}$ & $\%$ & $\mathbf{N}$ & $\%$ & \\
\hline \multicolumn{6}{|c|}{ Lymph node metastasis } \\
\hline N0 & 68 & 37.8 & & & \\
\hline N1 & 28 & 15.6 & & & \\
\hline $\mathrm{N} 2$ & 29 & 16.1 & & & \\
\hline N3 & 55 & 30.6 & & & \\
\hline \multicolumn{6}{|c|}{ Distant metastasis } \\
\hline M0 & 179 & 89.5 & & & \\
\hline M1 & 21 & 10.5 & & & \\
\hline \multicolumn{6}{|c|}{ Clinical stage } \\
\hline I & 14 & 7.2 & & & \\
\hline II & 16 & 8.2 & & & \\
\hline III & 143 & 73.7 & & & \\
\hline IV & 21 & 10.8 & & & \\
\hline
\end{tabular}

* $P$ values were obtained from $\mathrm{t}$-tests and chi-square tests.

sensitivities (at specificities of 95\%) were significantly increased by $15.7 \%$ and $9.1 \%$, respectively, relative to the combination of FliD and FlaA. Moreover, the AUCs for the combination of FliD, FlaA, NapA and CagA were not significantly greater than those of the combination of FliD, FlaA and NapA among the three populations mentioned above.

\section{DISCUSSION}

Currently, most countries lack national strategies or recommendations for early GC detection because no good screening methods are available. Hence, screening tests that can reliably evaluate $\mathrm{GC}$ subjects are urgently needed.

It has been proposed that the colonization of the gastric mucosa is a prerequisite for $H$. pylori infection and carcinogenesis and that motility is also essential for the initial colonization [17, 23, 24]. Flagella have been generally regarded as important virulence factors of pathogenic bacteria primarily because of the associated motility properties [25]. The FliD protein is thought to function as a capping structure at the distal end of the filament to assemble into a flagella [26, 27]. To our knowledge, only a single study, Kimmel et al. has examined the association between the FliD antibody and GC, and no association was found [28]. In the present study, seropositivity for the FliD antibody was associated with a 10.6-fold increase in the risk of GC. Our result is not in line with that of Kimmel et al., which may be attributable to the small sample size in the latter study (4 cases and 5 controls) or the existing diversity of $H$. pylori and genetic differences in host immune responses to $H$. pylori infection.

In the present study, a commercial ELISA method was used to detect the $H$. pylori infection statuses of the subjects. However, some studies have indicated that commercial ELISA serology may fail to detect past $H$. pylori infections and that patients with negative $H$. pylori serologic tests can actually be positive for antiCagA antibodies [29, 30]. At this point, the associations between GC and seropositivity for the FliD antibody were also analyzed in the $H$. pylori-negative and overall subjects. Additionally, strong, significant dose-response relationships between serum FliD antibody levels and GC were observed. These data suggest that attention should be focused on the antibody titer in addition to seropositivity.

Although CagA is an important and best-studied virulence factor of $H$. pylori, the association between the CagA antibody and the risk of GC remains controversial [31]. In the present study, we cloned a relatively conserved 2247-bp fragment of $\operatorname{cag} A$ extending from the $67^{\text {th }}$ to the $2313^{\text {th }} \mathrm{bp}$ to express the CagA protein because the fragments of approximately $65 \mathrm{bp}$ starting from the 5 '-end of the cag $A$ genes of different $H$. pylori isolates exhibit frequent mutations, and a variable EPIYA region at the $\mathrm{C}$-terminus and an important cleavage site preceding the first EPIYA motif also exist [32-34]. The OR for the risk 

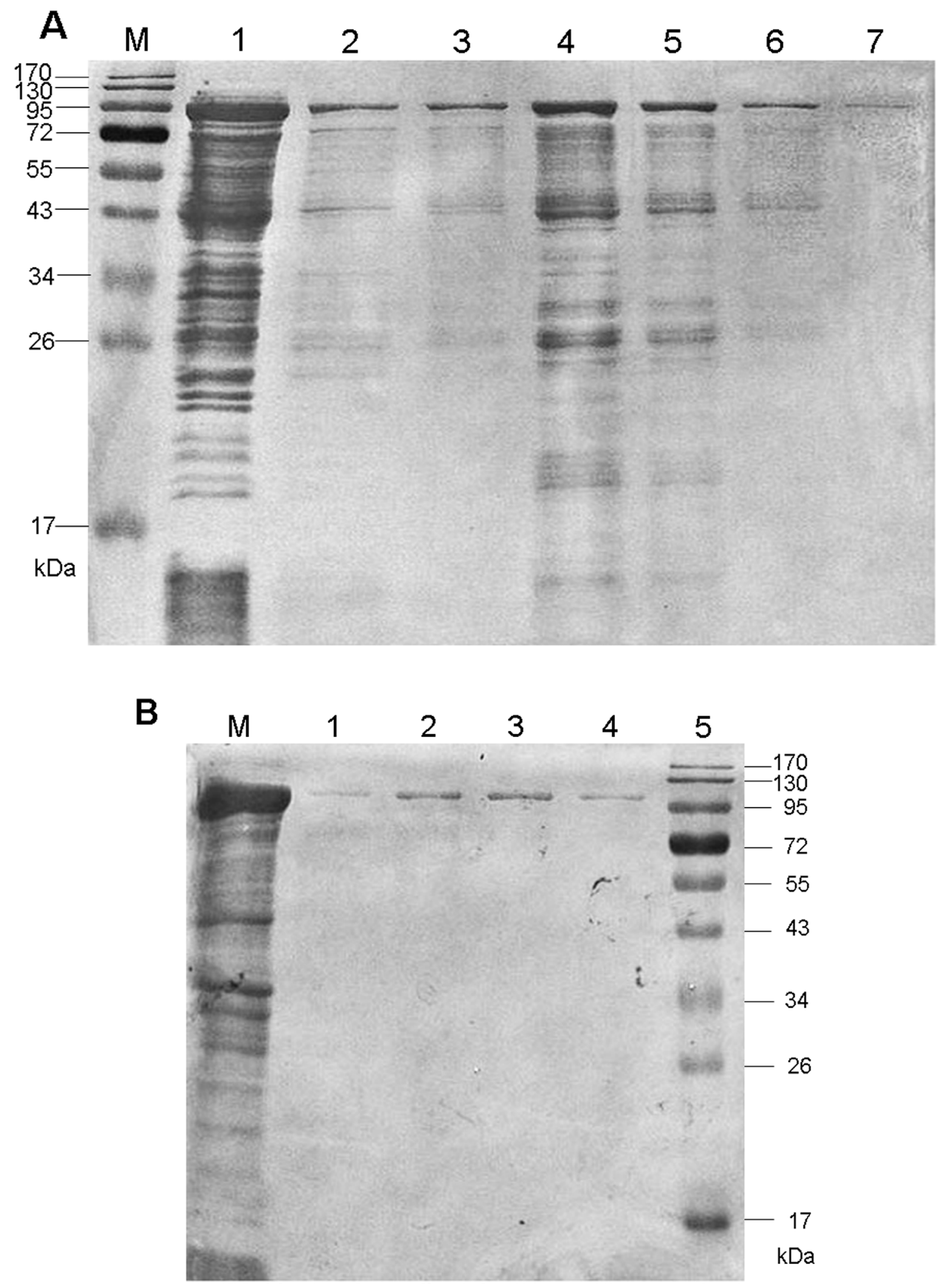

Figure 1: SDS-PAGE analyses of the purified recombinant proteins. A. FliD. B. CagA. 
Table 2: Associations of seropositivities for FliD and CagA antibodies with GC in the study subjects

\begin{tabular}{|c|c|c|c|c|c|c|c|c|c|c|c|c|}
\hline \multirow{2}{*}{$\begin{array}{l}\text { Virulence } \\
\text { factor } \\
\text { serostatus }\end{array}$} & \multicolumn{4}{|c|}{ H. pylori-positive subjects } & \multicolumn{4}{|c|}{ H. pylori-negative subjects } & \multicolumn{4}{|c|}{ Overall subjects } \\
\hline & $\begin{array}{c}\text { Case } \\
\text { N (\%) }\end{array}$ & $\begin{array}{c}\text { Control } \\
\text { N (\%) }\end{array}$ & $\begin{array}{c}\text { OR }(95 \% \\
\text { CI) }\end{array}$ & $P$ & $\begin{array}{c}\text { Case } \\
\text { N (\%) }\end{array}$ & $\begin{array}{c}\text { Control } \\
\text { N (\%) }\end{array}$ & $\begin{array}{c}\text { OR }(95 \% \\
\text { CII })^{b}\end{array}$ & $P$ & $\begin{array}{c}\text { Case } \\
\text { N (\%) }\end{array}$ & $\begin{array}{l}\text { Control } \\
\text { N (\%) }\end{array}$ & $\begin{array}{c}\text { OR }(95 \% \\
\text { CI) })^{b}\end{array}$ & $\boldsymbol{P}$ \\
\hline \multicolumn{13}{|l|}{ FliD } \\
\hline Negative & $\begin{array}{c}43 \\
(32.6)\end{array}$ & $99(82.5)$ & $\begin{array}{c}1.0 \\
\text { (Reference) }\end{array}$ & $<0.001$ & $\begin{array}{c}15 \\
(16.9)\end{array}$ & $58(44.6)$ & $\begin{array}{c}1.0 \\
\text { (Reference) }\end{array}$ & $<0.001$ & $\begin{array}{c}49 \\
(21.1)\end{array}$ & $171(64.3)$ & $\begin{array}{c}1.0 \\
\text { (Reference) }\end{array}$ & $<0.001$ \\
\hline Positive & $\begin{array}{c}89 \\
(67.4)\end{array}$ & $21(17.5)$ & $\begin{array}{c}10.6(5.2- \\
21.6)\end{array}$ & & $\begin{array}{c}74 \\
(83.1)\end{array}$ & $72(55.4)$ & $\begin{array}{c}6.5(3.0- \\
14.0)\end{array}$ & & $\begin{array}{c}183 \\
(78.9)\end{array}$ & $95(35.7)$ & $\begin{array}{c}7.6(4.7- \\
12.3)\end{array}$ & \\
\hline \multicolumn{13}{|l|}{ CagA } \\
\hline Negative & $\begin{array}{c}24 \\
(18.2)\end{array}$ & $51(42.5)$ & $\begin{array}{c}1.0 \\
\text { (Reference) }\end{array}$ & $<0.01$ & $\begin{array}{c}24 \\
(27.0)\end{array}$ & $56(43.1)$ & $\begin{array}{c}1.0 \\
\text { (Reference) }\end{array}$ & $<0.001$ & $\begin{array}{c}78 \\
(33.6)\end{array}$ & $150(56.4)$ & $\begin{array}{c}1.0 \\
\text { (Reference) }\end{array}$ & $<0.001$ \\
\hline Positive & $\begin{array}{c}108 \\
(81.8)\end{array}$ & $69(57.5)$ & $3.0(1.6-5.9)$ & & $\begin{array}{c}65 \\
(73.0)\end{array}$ & $74(56.9)$ & $\begin{array}{c}3.8(1.9- \\
7.7)\end{array}$ & & $\begin{array}{c}154 \\
(66.4)\end{array}$ & $116(43.6)$ & $\begin{array}{c}2.5(1.6- \\
3.8)\end{array}$ & \\
\hline
\end{tabular}

${ }^{\mathrm{b}}$ Adjusted for age, sex, BMI, education, smoking, alcohol consumption and family history of gastric cancer.

Table 3: Dose-dependent associations of GC risk with serum FliD and CagA antibody levels in the study subjects

\begin{tabular}{|c|c|c|c|c|c|c|c|c|c|c|c|c|c|c|}
\hline \multicolumn{5}{|c|}{ H. pylori positive subjects } & \multicolumn{5}{|c|}{ H. pylori negative subjects } & \multicolumn{5}{|c|}{ overall subjects } \\
\hline $\begin{array}{l}\text { Antibody } \\
\text { level (OD) }\end{array}$ & $\begin{array}{c}\text { Case } \\
\text { N (\%) }\end{array}$ & $\begin{array}{l}\text { Control } \\
\text { N }(\%)\end{array}$ & $\begin{array}{c}\text { OR }(95 \% \\
\text { CI })^{b}\end{array}$ & $P$ & $\begin{array}{c}\text { Antibody } \\
\text { level } \\
(\text { OD })^{*}\end{array}$ & $\begin{array}{c}\text { Case } \\
\text { N (\%) }\end{array}$ & $\begin{array}{l}\text { Control } \\
\text { N }(\%)\end{array}$ & $\begin{array}{c}\text { OR }(95 \% \\
\text { CI })^{\mathrm{b}}\end{array}$ & $P$ & $\begin{array}{c}\text { Antibody } \\
\text { level (OD)* }\end{array}$ & $\begin{array}{c}\text { Case } \\
\text { N (\%) }\end{array}$ & $\begin{array}{l}\text { Control } \\
\text { N (\%) }\end{array}$ & $\begin{array}{c}\text { OR }(95 \% \\
\text { CI })^{b}\end{array}$ & $P$ \\
\hline \multicolumn{15}{|l|}{ FliD } \\
\hline$>0.1914$ & $2(1.5)$ & $30(25.0)$ & $\begin{array}{c}1.0 \\
\text { (Reference) }\end{array}$ & $<0.001$ & $>0.1906$ & $2(2.3)$ & $32(24.6)$ & $\begin{array}{c}1.0 \\
\text { (Reference) }\end{array}$ & $<0.001$ & $>0.1841$ & $6(2.6)$ & $66(24.8)$ & $\begin{array}{c}1.0 \\
\text { (Reference) }\end{array}$ & $<0.001$ \\
\hline $\begin{array}{l}0.1313- \\
0.1914\end{array}$ & $12(9.1)$ & $30(25.0)$ & $\begin{array}{c}6.0(1.4- \\
25.2)\end{array}$ & & $\begin{array}{c}0.1345- \\
0.1906\end{array}$ & $10(11.2)$ & $33(25.4)$ & $\begin{array}{c}4.8(1.2- \\
19.7)\end{array}$ & & $\begin{array}{c}0.1345- \\
0.1841\end{array}$ & $19(8.2)$ & $67(25.2)$ & $3.1(1.3-7.7)$ & \\
\hline $\begin{array}{l}0.1057- \\
0.1313\end{array}$ & $22(16.7)$ & $29(24.2)$ & $\begin{array}{c}11.4(2.6- \\
49.1)\end{array}$ & & $\begin{array}{c}0.0932- \\
0.1345\end{array}$ & $26(29.2)$ & $33(25.4)$ & $\begin{array}{c}12.6(3.5- \\
44.7)\end{array}$ & & $\begin{array}{c}0.1028- \\
0.1345\end{array}$ & 49 (21.1) & $67(25.2)$ & $8.0(3.5-18.4)$ & \\
\hline$\leq 0.1057$ & $96(72.7)$ & $31(25.8)$ & $\begin{array}{c}46.5(14.7- \\
147.1)\end{array}$ & & $\leq 0.0932$ & $51(57.3)$ & $32(24.6)$ & $\begin{array}{c}25.5(7.0- \\
93.1)\end{array}$ & & $\leq 0.1028$ & $\begin{array}{c}158 \\
(68.1)\end{array}$ & $66(24.8)$ & $\begin{array}{l}26.3(13.7- \\
50.6)\end{array}$ & \\
\hline \multicolumn{15}{|l|}{ CagA } \\
\hline$>0.0544$ & $17(12.9)$ & $30(25.0)$ & $\begin{array}{c}1.0 \\
\text { (Reference) }\end{array}$ & $<0.001$ & $>0.0530$ & $10(11.2)$ & $31(23.8)$ & $\begin{array}{c}1.0 \\
\text { (Reference) }\end{array}$ & $<0.001$ & $>0.0531$ & $29(12.5)$ & $66(24.8)$ & $\begin{array}{c}1.0 \\
\text { (Reference) }\end{array}$ & $<0.001$ \\
\hline $\begin{array}{l}0.0400- \\
0.0544\end{array}$ & $23(17.4)$ & $29(24.2)$ & $1.4(0.6-3.0)$ & & $\begin{array}{c}0.0387- \\
0.0530\end{array}$ & $10(11.2)$ & $33(25.4)$ & $0.9(0.2-5.0)$ & & $\begin{array}{c}0.0393- \\
0.0531\end{array}$ & $37(15.9)$ & 63 (23.7) & $1.3(0.8-2.3)$ & \\
\hline $\begin{array}{l}0.0291- \\
0.0400\end{array}$ & $33(25.0)$ & $31(25.8)$ & $1.9(0.9-4.1)$ & & $\begin{array}{c}0.0270- \\
0.0387\end{array}$ & $23(25.9)$ & $33(25.4)$ & $2.2(0.9-5.7)$ & & $\begin{array}{c}0.0280- \\
0.0393\end{array}$ & $61(26.3)$ & $68(25.6)$ & $2.0(1.1-3.5)$ & \\
\hline$\leq 0.0291$ & $59(44.7)$ & $30(25.0)$ & $3.5(1.7-7.4)$ & & $\leq 0.0270$ & $46(51.7)$ & $33(25.4)$ & $\begin{array}{c}4.3(1.8- \\
10.3)\end{array}$ & & $\leq 0.0280$ & $\begin{array}{c}105 \\
(45.3)\end{array}$ & $69(25.9)$ & $3.5(2.1-5.8)$ & \\
\hline
\end{tabular}

${ }^{*}$ The Seropositivities for the antibody to FliD were categorized by antibody level quartiles in the controls.

of GC based on the anti-CagA antibody was higher in the $H$. pylori-negative population than in the $H$. pyloripositive and total populations. Our result is consistent with the result of a meta-analysis that suggested that $H$. pylorinegative/CagA-positive subjects may represent the group with the highest risk for GC [31]. However, the AUC for the CagA antibody in all subjects was 0.653 . AUCs in the range of 0.97 and above are generally considered to have excellent accuracies, AUCs of 0.93 to 0.96 are considered very good, AUCs of 0.75 to 0.92 are considered good, and AUCs below 0.75 should be cautiously evaluated because the associated tests have obvious deficiencies in accuracy that are approaching random $[35,36]$. According to these standard, the accuracy of CagA in the screening of the GC population in our study was poor, and this result is consistent with the conclusion of a meta-analysis that indicated that the CagA antibody should not be used as a GC marker in East Asian countries due to its AUC of 
Table 4: Sensitivities and specificities at different FliD and CagA critical values

\begin{tabular}{|c|c|c|c|c|c|c|c|c|c|}
\hline \multirow[b]{2}{*}{ Percentile $^{\mathrm{a}}$} & \multicolumn{3}{|c|}{ H. pylori positive subjects } & \multicolumn{3}{|c|}{ H. pylori negative subjects } & \multicolumn{3}{|c|}{ Overall subjects } \\
\hline & $\begin{array}{c}\text { critical } \\
\text { value }(\mathrm{OD})\end{array}$ & $\begin{array}{l}S n^{*} \\
(\%)\end{array}$ & $\begin{array}{l}S p^{*} \\
(\%)\end{array}$ & $\begin{array}{c}\text { critical } \\
\text { value }(O D)\end{array}$ & $\begin{array}{l}S n^{*} \\
(\%)\end{array}$ & $\begin{array}{l}S p^{*} \\
(\%)\end{array}$ & $\begin{array}{c}\text { critical } \\
\text { value }(\mathrm{OD})\end{array}$ & $\begin{array}{l}S n^{*} \\
(\%)\end{array}$ & $\begin{array}{l}S p^{*} \\
(\%)\end{array}$ \\
\hline \multicolumn{10}{|l|}{ FliD } \\
\hline $\begin{array}{l}\text { Optimal } \\
\text { cutoff point }\end{array}$ & 0.1007 & 67.4 & 82.5 & 0.1263 & 83.1 & 55.4 & 0.1153 & 78.9 & 64.3 \\
\hline $25 \%$ & 0.1057 & 72.0 & 75.8 & 0.0932 & 57.3 & 75.4 & 0.1028 & 68.1 & 75.2 \\
\hline $50 \%$ & 0.1313 & 89.4 & 50.0 & 0.1345 & 86.5 & 50.0 & 0.1345 & 89.2 & 50.0 \\
\hline $75 \%$ & 0.1914 & 98.5 & 25.0 & 0.1906 & 97.8 & 24.6 & 0.1841 & 97.4 & 24.8 \\
\hline $90 \%$ & 0.2694 & 100.0 & 10.0 & 0.2688 & 98.9 & 10.0 & 0.2676 & 99.6 & 9.8 \\
\hline \multicolumn{10}{|l|}{ CagA } \\
\hline $\begin{array}{l}\text { Optimal } \\
\text { cutoff point }^{\text {b }}\end{array}$ & 0.0463 & 81.8 & 42.5 & 0.0367 & 73.0 & 56.9 & 0.0463 & 83.2 & 39.1 \\
\hline $25 \%$ & 0.0291 & 44.7 & 75.0 & 0.0270 & 50.6 & 76.9 & 0.0280 & 45.3 & 75.9 \\
\hline $50 \%$ & 0.0400 & 68.9 & 50.8 & 0.0387 & 77.5 & 50.8 & 0.0393 & 70.7 & 50.4 \\
\hline $75 \%$ & 0.0544 & 87.1 & 25.0 & 0.0530 & 88.8 & 25.4 & 0.0531 & 87.5 & 24.8 \\
\hline $90 \%$ & 0.0696 & 97.0 & 10.0 & 0.0716 & 96.6 & 10.0 & 0.0701 & 96.6 & 9.8 \\
\hline
\end{tabular}

aPercentiles of the serum FliD antibody levels in the controls; * $S n$, Sensitivity; $S p$, Specificity.

'The optimal cutoff points for the different biomarkers were based on the maximum Youden's indices (sensitivity + specificity-1).

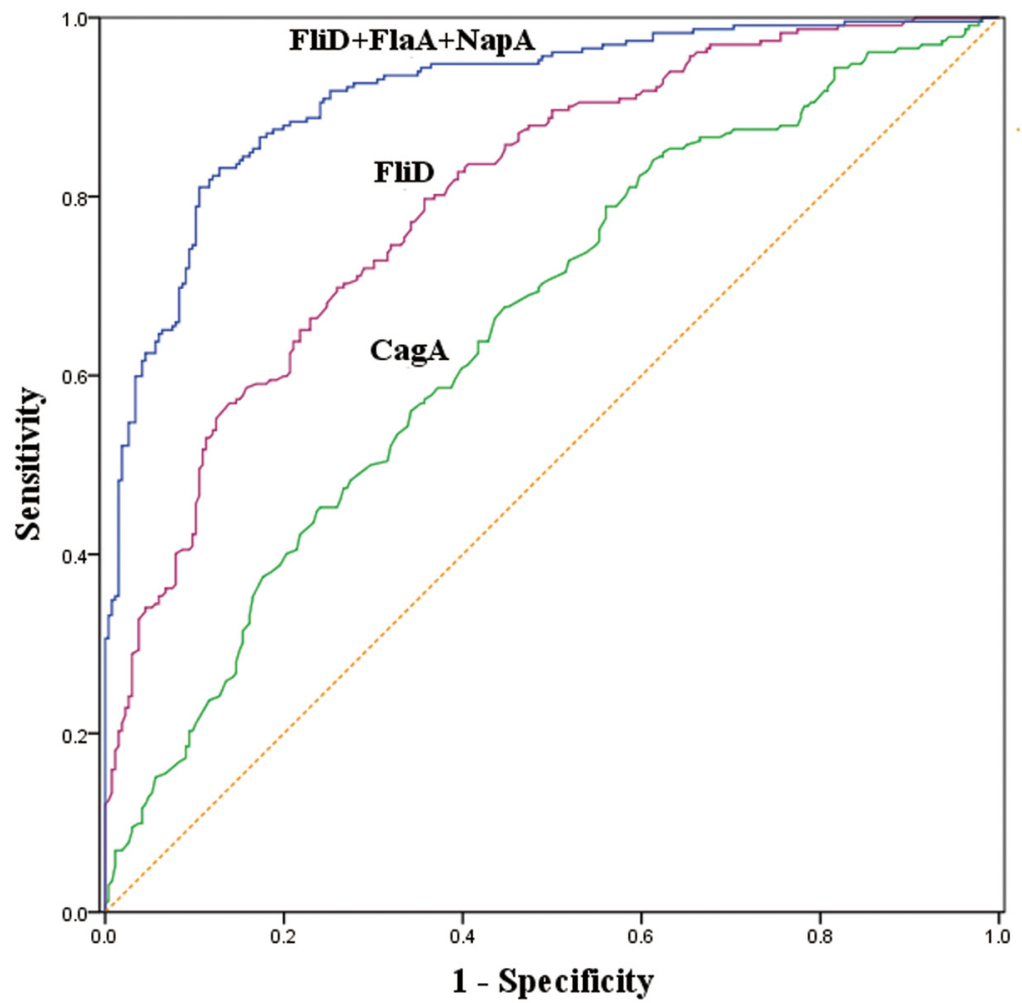

Figure 2: Receiver operating characteristic (ROC) curves of the predictive performances of the serum FliD antibody, CagA antibody and the combination of FliD, FlaA and NapA antibodies in the overall subjects. 
Table 5: AUCs and sensitivities of the combination of FliD, FlaA, NapA and CagA for GC

\begin{tabular}{|c|c|c|c|c|c|c|}
\hline Marker combination & $\begin{array}{c}\text { AUC } \\
(95 \% \text { CI })\end{array}$ & $\begin{array}{l}p \text {-value for } \\
\text { comparison of } \\
\text { AUC to FliD }\end{array}$ & $\begin{array}{c}90 \% \\
\text { Specificity } \\
(\%)\end{array}$ & $\begin{array}{c}95 \% \\
\text { Specificity } \\
(\%)\end{array}$ & $\begin{array}{c}98 \% \\
\text { Specificity } \\
(\%)\end{array}$ & $\begin{array}{c}p \text {-value for } \\
\text { comparison of } \\
\text { sensitivity at } \\
95 \% \text { specificity } \\
\text { to FliD }\end{array}$ \\
\hline \multicolumn{7}{|l|}{ H. pylori-positive subjects } \\
\hline FliD & $\begin{array}{c}0.821(0.768- \\
0.867)\end{array}$ & N/A & 56.1 & 39.4 & 22.7 & N/A \\
\hline FliD + FlaA & $\begin{array}{c}0.913(0.871- \\
0.945)\end{array}$ & $<0.001$ & 66.7 & 60.6 & 50.0 & $<0.001$ \\
\hline FliD+ NapA & $\begin{array}{c}0.822(0.769- \\
0.867)\end{array}$ & 0.657 & 56.1 & 40.9 & 25.0 & 0.617 \\
\hline FliD + FlaA+NapA & $\begin{array}{c}0.918(0.877- \\
0.949)\end{array}$ & $<0.001$ & 77.3 & 61.4 & 53.0 & $<0.001$ \\
\hline FliD + FlaA + NapA + CagA & $\begin{array}{c}0.916(0.875- \\
0.947)\end{array}$ & $<0.001$ & 72.0 & 62.9 & 51.5 & $<0.001$ \\
\hline \multicolumn{7}{|l|}{ H. pylori-negative subjects } \\
\hline FliD & $\begin{array}{c}0.764(0.702- \\
0.818)\end{array}$ & N/A & 30.3 & 25.8 & 14.6 & N/A \\
\hline FliD + FlaA & $\begin{array}{c}0.891(0.842- \\
0.929)\end{array}$ & $<0.001$ & 61.8 & 36.0 & 24.7 & 0.164 \\
\hline FliD+ NapA & $\begin{array}{c}0.791(0.731- \\
0.843)\end{array}$ & 0.094 & 42.7 & 22.5 & 14.6 & 0.579 \\
\hline FliD + FlaA+NapA & $\begin{array}{c}0.897(0.849- \\
0.934)\end{array}$ & $<0.001$ & 60.7 & 51.7 & 29.2 & $<0.001$ \\
\hline $\mathrm{FliD}+\mathrm{FlaA}+\mathrm{NapA}+\mathrm{CagA}$ & $\begin{array}{c}0.908(0.862- \\
0.943)\end{array}$ & $<0.001$ & 65.2 & 47.2 & 22.5 & 0.004 \\
\hline \multicolumn{7}{|l|}{ Overall subjects } \\
\hline FliD & $\begin{array}{c}0.800(0.762- \\
0.834)\end{array}$ & N/A & 32.8 & 21.1 & 12.5 & N/A \\
\hline FliD + FlaA & $\begin{array}{c}0.907(0.878- \\
0.931)\end{array}$ & $<0.001$ & 54.3 & 43.1 & 31.9 & $<0.001$ \\
\hline FliD+ NapA & $\begin{array}{c}0.805(0.767- \\
0.839)\end{array}$ & 0.278 & 33.6 & 22.4 & 14.7 & 0.450 \\
\hline FliD + FlaA+NapA & $\begin{array}{c}0.915(0.887- \\
0.938)\end{array}$ & $<0.001$ & 61.6 & 52.2 & 33.2 & $<0.001$ \\
\hline $\mathrm{FliD}+\mathrm{FlaA}+\mathrm{NapA}+\mathrm{CagA}$ & $\begin{array}{c}0.915(0.887- \\
0.938)\end{array}$ & $<0.001$ & 63.8 & 44.0 & 27.2 & $<0.001$ \\
\hline
\end{tabular}

0.636 [37]. Therefore, we focused on other potentially carcinogenic $H$. pylori virulence factors including FliD.

Although gastroscopy and biopsy are reliable methods for GC detection, these procedures are invasive, time-consuming and expensive; therefore, it is necessary to search for ideal biomarkers of GC. Many conventional biomarkers, such as the carcinoembryonic antigen (CEA), cancer antigen 19-9 (CA19-9), and cancer antigen 72-4 (CA72-4), are widely utilized in the clinic, but low sensitivities or low specificities reduce the clinical practical value of these markers for the early diagnosis of GC [38-40]. With the increase quantity of in-depth research into biomarkers for $\mathrm{GC}$, increasing attention has been focused on the use of circulating nucleic acids as novel biomarkers. However, DNA/RNA extraction and bisulfite conversion are too time-intensive for clinical use [41-43]. Therefore, additional studies should be performed to identify the most promising markers for the potential future screening of GC. Emerging evidence has revealed that many $H$. pylori virulence factors promote 
the development of GC [44]. Additionally, seropositivities for antibodies against some of these $H$. pylori virulence factors have been identified as biomarkers of GC [45, 46]. The $H$. pylori flagellar virulence factor FliD has been identified as an efficient tool for the detection of $H$. pylori infections via measurements of the levels of the antibody to this factor in the serum [18]. In the present study, we explored the value of the serum FliD antibody as a biomarker for distinguishing GC patients from controls. Additionally, the significance of combinations of the FliD, FlaA, NapA and CagA antibodies were assessed. We found that FliD may be an independent biomarker based on the associated AUC of 0.800 in the overall group subjects and that the combination of FliD, FlaA and NapA exhibited a higher validity in the detection of GC with the AUC of 0.915 .

Overall, the FliD antibody may be an independent biomarker for GC patients, and the combination of FliD, FlaA and NapA performed even better. However, our findings were obtained in a case-control study, and additional larger prospective studies are needed to expand and confirm these findings.

\section{MATERIALS AND METHODS}

\section{Study subjects}

A hospital-based case-control study was performed in Harbin, Heilongjiang Province, China. All 232 cases with pathologically confirmed GC were enrolled from the Third Affiliated Hospital of Harbin Medical University between March and June of 2010. Additionally, 183 healthy individuals who underwent physical examinations at the Center for Disease Control of Xiangfang District, Harbin between April and July of 2010 and 83 cancer-free neurological patients of the Fourth Affiliated Hospital of Harbin Medical University between March and May of 2011 were included as controls. All participants completed a face-to-face questionnaire and provided written informed consent. A blood sample was drawn from each consenting participant according to a research protocol approved by the Human Research and Ethics Committee of Harbin Medical University. All blood samples were centrifuged and stored at $-80^{\circ} \mathrm{C}$ until use.

\section{Serologic tests for $\boldsymbol{H}$. pylori by ELISA}

H. pylori IgG antibodies were measured in duplicate using an enzyme immunoassay kit (IBL, Germany). The sensitivity and specificity of the kit were both greater than $95 \%$ according to the manufacturer.

\section{Recombinant protein cloning and expression}

The genomic DNA of a clinical strain provisionally named HLJ014a was extracted using a DNA extraction kit (Qiagen, USA) and stored at $-80^{\circ} \mathrm{C}$. Briefly, the fulllength $f i D$ gene was amplified by polymerase chain reaction (PCR) using the genomic DNA as the template. Oligonucleotide primers were designed based on the published literature [18]. Subsequently, EcoRI sites were introduced into the $5^{\prime}$ ends of the forward primers, and XhoI sites were inserted into the $5^{\prime}$ ends of the reverse primers. The target DNA amplification product was cloned into the pMD19T (simple) cloning vector and then transformed into $E$. coli strain DH5 $\alpha$. The positive recombinants were confirmed by bacterial solution PCR, restriction enzyme digestion and DNA sequencing. The digested gel-purified $f i D$ gene was ligated into the expression vector $p E T-32 a(+)$. The recombinant plasmid $p E T 32 a-f l D$ was transformed into E. coli BL21DE3 cells, transformation was confirmed, and the cells were inoculated into LB medium with $100 \mu \mathrm{g} / \mathrm{mL}$ ampicillin. Expression was induced via the addition of IPTG at a final concentration of $1.0 \mathrm{mmol} / \mathrm{L}$ at $30^{\circ} \mathrm{C}$ and an optical density (OD) of 0.6-0.8. The E. coli cells were harvested after 4 hours and lysed via ultrasonication. The suspension was collected and examined with $15 \%$ SDS-PAGE. The soluble histidine-tagged protein was purified with Ni-NTA His Bind resin (Novagen, Germany).

We also used the method described above to obtain the purified CagA protein. For the PCR, the primers were designed to amplify a relatively conserved 2247-bp cagA fragment extending from the $67^{\text {th }}$ to the $2313^{\text {th }}$ bp at the 5 ' end of the $\operatorname{cag} A$ gene of $H$. pylori strain 26695. IPTG was added to the LB-Amp broth at $30^{\circ} \mathrm{C}$ to induce CagA protein expression.

\section{Enzyme-linked immunosorbent assay (ELISA)}

The presences of serum IgG antibodies to the recombinant FliD and CagA were determined by indirect ELISA. Ninety-six-well plates (Costar, USA) were coated with $100 \mu \mathrm{L} /$ well of purified FliD or CagA protein diluted to $0.5 \mu \mathrm{g} / \mathrm{mL}$ and $0.25 \mu \mathrm{g} / \mathrm{mL}$, respectively, and incubated overnight at $4^{\circ} \mathrm{C}$. After washing three times with $300 \mu \mathrm{L}$ phosphate-buffered saline tween (PBST) $(0.15 \mathrm{~mol} / \mathrm{L}$ phosphate buffer, $0.05 \%$ Tween-20, pH 7.4), the ELISA plates were blocked in a moist chamber with $200 \mu \mathrm{L}$ PBS containing $1 \%$ bovine serum albumin (BSA) (Amresco, USA) per well for 2 hours at $37^{\circ} \mathrm{C}$. All serologic samples (3600-fold diluted with $0.1 \%$ BSA, phosphate buffer) were then added to the microtiter wells and incubated at $37^{\circ} \mathrm{C}$ for 1 hour. After three washes, 1:10000 or 1:5000 of 100 $\mu \mathrm{L}$ peroxidase-conjugated goat anti-human IgG (ZSGBBio, Beijing, China) were loaded into each well for FliD and CagA, respectively, and the plates were incubated for 30 minutes at $37^{\circ} \mathrm{C}$. The plates were washed, and TMB substrate $(100 \mu \mathrm{L})$ was then added to the plates, which were then incubated at $37^{\circ} \mathrm{C}$ for 15 minutes. The reaction was terminated with the addition of $50 \mu \mathrm{L}$ of $2 \mathrm{M}$ sulfuric acid solution. Finally, the density of each serum sample was 
measured at the dual wavelengths of 450 and $630 \mathrm{~nm}$ in a microplate reader (BioTek Synergy 2, USA). Each serum sample was tested in triplicate. Additionally, $100 \mu \mathrm{L}$ PBS containing $0.1 \%$ BSA was added to the wells as a control.

\section{Statistical analysis}

We used the t-test to compare the means of the continuous variables between the patients and controls, and the chi-square test was used to compare the distributions of the various characteristics between the different groups. The ELISA values for FliD and CagA were tested with the K-S test following logarithmic conversion. The ELISA result for a patient's serum sample was considered positive if the absorbance (OD450) was less than or equal to the optimal cutoff OD value. Unconditional logistic-regression analysis was conducted to assess the associations between FliD, CagA and GC. To determine the relative risks, ORs and 95\% confidence intervals (CIs) were calculated. The chi-square trend test was used to measure the doseresponse relationships between the serum FliD and CagA antibody levels and GC. The sensitivities, specificities, and AUCs with the 95\% CIs were also calculated. Furthermore, the ELISA values for FliD, FlaA, NapA and CagA were combined with discriminant analysis through the predicted probability for each subject. The AUCs of the combinations were also computed. A test result was considered positive if it was less than or equal to a selected predicted probability and negative if it was greater than a selected predicted probability. According to the selected predicted probability, the sensitivities were obtained at set specificities of $90 \%, 95 \%$, and $98 \%$. All of the abovementioned statistical analyses were performed with SPSS statistics 17.0 , and with $P$ values $<0.05$ were considered statistically significant.

\section{ACKNOWLEDGMENTS}

This study was funded by the National Natural Science Foundation of China (2016-2019, Grant No. 81573219).

\section{CONFLICTS OF INTEREST} interest.

The authors declare that they have no conflicts of

\section{Abbreviations}

FliD, flagellar hook-associated protein; CagA, cytotoxin-associated gene A; FlaA, flagellin A; NapA, neutrophil-activating protein; GC, gastric cancer; H. pylori, Helicobacter pylori; WHO, World Health Organization; IARC International Agency for Research on Cancer; PCR, polymerase chain reaction; CAG, chronic atrophy gastritis; ELISA, enzyme-linked immunosorbent assay; OD, optical density; OR, odds ratio; CI, confidence interval; ROC, receiver operating characteristic; AUC, area under the ROC curve; SDS-PAGE, sodium dodecyl sulfate polyacrylamide gel electrophoresis; PBST, phosphate-buffered saline tween; BSA, bovine serum albumin; CEA, carcinoembryonic antigen; CA19-9, cancer antigen 19-9; CA72-4, cancer antigen 72-4.

\section{REFERENCES}

1. Ferlay J, Soerjomataram I, Dikshit R, Eser S, Mathers C, Rebelo M, Parkin DM, Forman D, Bray F. Cancer incidence and mortality worldwide: sources, methods and major patterns in GLOBOCAN 2012. Int J Cancer. 2015; 136:E359-386.

2. Dixon MF, Genta RM, Yardley JH, Correa P. Classification and grading of gastritis. The updated Sydney System. International Workshop on the Histopathology of Gastritis, Houston 1994. Am J Surg Pathol. 1996; 20:1161-1181.

3. Rugge M, Cassaro M, Pennelli G, Leandro G, Di Mario F, Farinati F. Atrophic gastritis: pathology and endoscopy in the reversibility assessment. Gut. 2003; 52:1387-1388.

4. Bouvard V, Baan R, Straif K, Grosse Y, Secretan B, El Ghissassi F, Benbrahim-Tallaa L, Guha N FC, Galichet L, Cogliano V. A review of human carcinogens-Part B: biological agents. Lancet Oncol. 2009; 10:321-322.

5. Eslick GD, Lim LL, Byles JE, Xia HH, Talley NJ. Association of Helicobacter pylori infection with gastric carcinoma: a meta-analysis. Am J Gastroenterol. 1999; 94:2373-2379.

6. Fuccio L, Zagari RM, Eusebi LH, Laterza L, Cennamo V, Ceroni L, Grilli D, Bazzoli F. Meta-analysis: can Helicobacter pylori eradication treatment reduce the risk for gastric cancer. Ann Intern Med. 2009; 151:121-128.

7. Suerbaum S, Michetti P. Helicobacter pylori infection. N Engl J Med. 2002; 347:1175-1186.

8. Peek RJ, Crabtree JE. Helicobacter infection and gastric neoplasia. J Pathol. 2006; 208:233-248.

9. Wroblewski LE, Peek RJ, Wilson KT. Helicobacter pylori and gastric cancer: factors that modulate disease risk. Clin Microbiol Rev. 2010; 23:713-739.

10. Yamaoka Y. Mechanisms of disease: Helicobacter pylori virulence factors. Nat Rev Gastroenterol Hepatol. 2010; 7:629-641.

11. Song H, Michel A, Nyren O, Ekstrom AM, Pawlita M, Ye W. A CagA-independent cluster of antigens related to the risk of noncardia gastric cancer: associations between Helicobacter pylori antibodies and gastric adenocarcinoma explored by multiplex serology. Int J Cancer. 2014; 134:2942-2950.

12. Epplein M, Zheng W, Xiang YB. Prospective study of Helicobacter pylori biomarkers for gastric cancer risk among Chinese men. Cancer Epidemiol Biomarkers Prev. 2012; 21:2185-2192. 
13. Lin YF, Wu MS, Chang CC, Lin SW, Lin JT, Sun YJ, Chen DS, Chow LP. Comparative immunoproteomics of identification and characterization of virulence factors from Helicobacter pylori related to gastric cancer. Mol Cell Proteomics. 2006; 5:1484-1496.

14. Kim JS, Chang JH, Chung SI, Yum JS. Molecular cloning and characterization of the Helicobacter pylori fliD gene, an essential factor in flagellar structure and motility. J Bacteriol. 1999; 181:6969-6976.

15. Moens S, Vanderleyden J. Functions of bacterial flagella. Crit Rev Microbiol. 1996; 22:67-100.

16. Ottemann KM, Miller JF. Roles for motility in bacterialhost interactions. Mol Microbiol. 1997; 24:1109-1117.

17. Ottemann KM. Helicobacter pylori uses motility for initial colonization and to attain robust infection. Infect Immun. 2002; 70:1984-1990.

18. Khalifeh Gholi M, Kalali B, Formichella L, Göttner G, Shamsipour F, Zarnani AH, Hosseini M, Busch DH, Shirazi MH, Gerhard M. Helicobacter pylori FliD protein is a highly sensitive and specific marker for serologic diagnosis of H. pylori infection. Int J Med Microbiol. 2013; 303:618-623.

19. Tian W, Jia Y, Yuan K, Huang L, Nadolny C, Dong X, Ren X, Liu J. Serum antibody against Helicobacter pylori FlaA and risk of gastric cancer. Helicobacter. 2014; 19:9-16.

20. Liu J, Liu H, Zhang T, Ren X, Nadolny C, Dong X, Huang L, Yuan K, Tian W, Jia Y. Serum Helicobacter pylori NapA antibody as a potential biomarker for gastric cancer. Sci Rep. 2014; 4:4143.

21. Alm RA, Ling LS, Moir DT, King BL, Brown ED, Doig PC, Smith DR, Noonan B, Guild BC, deJonge BL, Carmel G, Tummino PJ, Caruso A, et al. Genomic-sequence comparison of two unrelated isolates of the human gastric pathogen Helicobacter pylori. Nature. 1999; 397:176-180.

22. Tomb JF, White O, Kerlavage AR, Clayton RA, Sutton GG, Fleischmann RD, Ketchum KA, Klenk HP, Gill S, Dougherty BA, Nelson K, Quackenbush J, Zhou L, et al. The complete genome sequence of the gastric pathogen Helicobacter pylori. Nature. 1997; 388:539-547.

23. Conteduca V, Sansonno D, Lauletta G, Russi S, Ingravallo G, Dammacco F. H. pylori infection and gastric cancer: state of the art (review). Int J Oncol. 2013; 42:5-18.

24. Correa P, Houghton J. Carcinogenesis of Helicobacter pylori. Gastroenterology. 2007; 133:659-672.

25. Duan Q, Zhou M, Zhu L, Zhu G. Flagella and bacterial pathogenicity. J Basic Microbiol. 2013; 53:1-8.

26. Ikeda $\mathrm{T}$, Homma M, Iino $\mathrm{T}$, Asakura S, Kamiya R. Localization and stoichiometry of hook-associated proteins within Salmonella typhimurium flagella. J Bacteriol. 1987; 169:1168-1173.

27. Ikeda T, Yamaguchi S, Hotani H. Flagellar growth in a filament-less Salmonella fliD mutant supplemented with purified hook-associated protein 2. J Biochem. 1993; 114:39-44.
28. Kimmel B, Bosserhoff A, Frank R, Gross R, Goebel W, Beier D. Identification of immunodominant antigens from Helicobacter pylori and evaluation of their reactivities with sera from patients with different gastroduodenal pathologies. Infect Immun. 2000; 68:915-920.

29. Ekström AM, Held M, Hansson LE, Engstrand L, Nyrén O. Helicobacter pylori in gastric cancer established by CagA immunoblot as a marker of past infection. Gastroenterology. 2001; 121:784-791.

30. Annibale B, Lahner E, Santucci A, Vaira D, Pasquali A, Severi C, Mini R, Figura N, Delle FG. CagA and VacA are immunoblot markers of past Helicobacter pylori infection in atrophic body gastritis. Helicobacter. 2007; 12:23-30.

31. Shiota S, Matsunari O, Watada M, Yamaoka Y. Serum Helicobacter pylori CagA antibody as a biomarker for gastric cancer in east-Asian countries. Future Microbiol. 2010; 5:1885-1893.

32. Yan J, Wang Y, Shao SH, Mao YF, Li HW, Luo YH. Construction of prokaryotic expression system of 2 148bp fragment from cagA gene and detection of cagA gene, CagA protein in Helicobacter pylori isolates and its antibody in sera of patients. World J Gastroenterol. 2004; 10:1183-1190.

33. Angelini A, Tosi T, Mas P, Acajjaoui S, Zanotti G, Terradot L, Hart DJ. Expression of Helicobacter pylori CagA domains by library-based construct screening. FEBS J. 2009; 276:816-824.

34. González L, Marrero K, Reyes O, Rodríguez E, Martínez $\mathrm{L}$, Rodríguez BL. Cloning and expression of a recombinant CagA-gene fragment of Helicobacter pylori and its preliminary evaluation in serodiagnosis. Biomedica. 2013; 33:546-553.

35. Jones CM, Athanasiou T. Summary receiver operating characteristic curve analysis techniques in the evaluation of diagnostic tests. Ann Thorac Surg. 2005; 79:16-20.

36. Walter SD. Properties of the summary receiver operating characteristic (SROC) curve for diagnostic test data. Stat Med. 2002; 21:1237-1256.

37. Zhao Z, Li Y, Liu S, Fu W. Serum Helicobacter pylori CagA antibody may not be used as a marker for diagnosing gastric cancer in east Asian countries. Tumour Biol. 2014; 35:12217-12224.

38. Emoto S, Ishigami H, Yamashita H, Yamaguchi H, Kaisaki S, Kitayama J. Clinical significance of CA125 and CA72-4 in gastric cancer with peritoneal dissemination. Gastric Cancer. 2012; 15:154-161.

39. Kanda M, Fujii T, Takami H, Suenaga M, Inokawa Y, Yamada S, Nakayama G, Sugimoto H, Koike M, Nomoto S, Kodera Y. Combination of the serum carbohydrate antigen 19-9 and carcinoembryonic antigen is a simple and accurate predictor of mortality in pancreatic cancer patients. Surg Today. 2014; 44:1692-1701.

40. Ebert MP, Röcken C. Molecular screening of gastric cancer by proteome analysis. Eur J Gastroenterol Hepatol. 2006; 18:847-853. 
41. Liu HS, Xiao HS. MicroRNAs as potential biomarkers for gastric cancer. World J Gastroenterol. 2014; 20:12007-12017.

42. Tahara T, Arisawa T. DNA methylation as a molecular biomarker in gastric cancer. Epigenomics. 2015; 7:475-486.

43. Kanda M, Kodera Y. Recent advances in the molecular diagnostics of gastric cancer. World J Gastroenterol. 2015; 21:9838-9852.

44. Shiota S, Suzuki R, Yamaoka Y. The significance of virulence factors in Helicobacter pylori. J Dig Dis. 2013; $14: 341-349$
45. Gao L, Michel A, Weck MN, Arndt V, Pawlita M, Brenner H. Helicobacter pylori infection and gastric cancer risk: evaluation of $15 \mathrm{H}$. pylori proteins determined by novel multiplex serology. Cancer Res. 2009; 69:6164-6170.

46. Krah A, Miehlke S, Pleissner KP, Zimny-Arndt U, Kirsch C, Lehn N, Meyer TF, Jungblut PR, Aebischer T. Identification of candidate antigens for serologic detection of Helicobacter pylori-infected patients with gastric carcinoma. Int J Cancer. 2004; 108:456-463. 